\title{
Changes in ascorbic acid and total phenolics contents associated with browning inhibition of pineapple slices
}

\author{
Lidia Elena AYÓN-REYNA ${ }^{1}$, Lourdes Guadalupe AYÓN-REYNA¹, Martha Edith LÓPEZ-LÓPEZ1, \\ Gabriela LÓPEZ-ANGULO ${ }^{1}$, Karen Virginia PINEDA-HIDALGO ${ }^{1}$, Jorge Aurelio ZAZUETA-NIEBLA ${ }^{1}$, \\ Misael Odín VEGA-GARCÍA ${ }^{1 *}$
}

\begin{abstract}
Pineapple slices were treated with three antioxidants and stored under passive modified atmosphere packaging (MAP) to evaluate the effect of these treatments on tissue browning (percentage of dark area) and the accumulation of ascorbic acid and total phenolics. Pineapple slices were immersed in ascorbic acid (AA), isoascorbic acid (IAA), and $N$-acetylcysteine (NAC) solutions for $2 \mathrm{~min}$, and then were packed and stored at $5{ }^{\circ} \mathrm{C}$ under air (AIR) or MAP for 15 days. Water was used as control. The application of IAA and NAC under passive MAP reduced better the tissue browning index and maintained a good quality of the slices. The use of AA and IAA increased the contents of ascorbic acid and total phenolics. The application of IAA followed by storage under MAP conditions was effective in reducing tissue browning, which was associated with a higher retention of ascorbic acid and total phenolics contents of the pineapple slices.
\end{abstract}

Keywords: fresh-cut; ascorbic acid; phenolic compounds; enzymatic browning; isoascorbic acid; $N$-acetylcysteine.

Practical Application: Results may benefit the fresh-cut pineapple industry attending the current consumer preferences.

\section{Introduction}

Modern lifestyles and the increase in health-conscious consumers have stimulated an increment in the demand for fresh-cut fruits due to the health benefits associated with these food products (Remorini et al., 2015). Nevertheless, the mechanical operations used during the minimal processing result in damage to the tissue, affecting its nutritional properties due to an increase in the metabolic activity and associated enzymatic reactions (Luo et al., 2014). Pineapple is a tropical fruit considered a rich source of ascorbic acid (vitamin C) and phenolic compounds that can prevent the development of cancer and cardiovascular diseases. This fruit is mainly used for processing; nevertheless, fresh-cut pineapples rapidly deteriorate, showing browning problems once processed, being polyphenol oxidase (PPO; E.C. 1.14.18.1) the main enzyme involved (Oms-Oliu et al., 2006; Chiabrando \& Giacalone, 2012). Its action reduces the availability of phenolic compounds, which are of nutritional interest to the consumers.

Some antioxidant compounds have used to inhibit browning and to preserve the nutritional quality of fresh-cut products. Ascorbic acid (AA) has been considered a highly effective inhibitor of browning due to its ability to reduce quinones to their phenolic form before they can react with PPO to form pigments (Remorini et al., 2015). In this sense, Abbasi et al. (2013) reported lower browning index and PPO activity as well as higher total phenolics content in loquat fruit treated with ascorbic acid than in untreated fruit. Chiabrando \& Giacalone (2012) reported that ascorbic acid significantly reduced the browning of fresh-cut apple. Moreover, Cefola et al. (2014) showed the beneficial effect of ascorbic acid in combination with calcium lactate in preserving quality and microbiological traits of fresh-cut nectarines. The isoascorbic acid (IAA) is also used to reduce browning, due to its ability to reduce the quinones to its corresponding phenolics, and also because it acts as a chelating agent and seems to be a competitive inhibitor of PPO. Kumar et al. (2013) reported a lower browning index and PPO activity as well as higher ascorbic acid content in litchi treated with isoascorbic acid compared with the untreated fruit. Amino acids with a thiol group, such as cysteine, are very effective to inhibit PPO because they react with phenolic substrates and quinones preventing the formation of colored compounds. González-Aguilar et al. (2005) observed that application of $\mathrm{N}$-acetylcysteine (NAC) was effective in preventing browning of fresh-cut pineapple; phenolics content was also higher in treated than in untreated fruit, which was correlated with a lower PPO activity.

In addition, storage under atmospheric modifications has been considered an effective alternative to extend the shelf life of fresh-cut products, given that it reduces the loss of water, the browning in the cut surface, the respiration rate, ethylene biosynthesis, as well as microbial growth (Oliveira et al., 2015). One type of atmospheric alteration is called passive modified atmosphere and consists in the natural modification of the internal atmosphere created by the product (Gorny et al., 2002). Passive modified atmosphere is commonly used in the packaging of different products and is also known as modified atmosphere packaging (MAP). 
Considering the existence of the above commercial alternatives and the current consumer preferences for natural products that ensure adequate contents of healthy compounds, the aim of this work was to evaluate the effect of the application of three antioxidant agents (AA, IAA, and NAC) alone or in combination with passive MAP on ascorbic acid and total phenolics contents when they are applied to inhibit browning and preserve the quality of pineapple slices stored at $5^{\circ} \mathrm{C}$.

\section{Materials and methods}

\subsection{Fruit processing}

Pineapple (Ananas comosus) cv. Cayena lisa was obtained from a local market in Culiacan, Sinaloa, Mexico at commercial maturity stage, with an average content of soluble solids of $11^{\circ} \mathrm{Brix}$ and a firmness of $19 \mathrm{~N}$. Fruits were washed and disinfected with sodium hypochlorite $(100 \mu \mathrm{L} / \mathrm{L})$ and then were peeled and transversely cut to form $1 \mathrm{~cm}$ thick slices. Later, the cores were removed and half-moon like slices were made. Slices were divided into four lots for the application of the different antioxidant solutions: ascorbic acid (AA, $0.05 \mathrm{mM}$ ), isoascorbic acid (IAA, $0.1 \mathrm{mM}$ ) and $\mathrm{N}$-acetylcysteine (NAC, $0.05 \mathrm{mM}$ ) along with the control treatment (dipped in purified water). All immersions were done at $5{ }^{\circ} \mathrm{C}$ for $2 \mathrm{~min}$. Each lot was divided into two groups. For the first group, treated slices were put into low density polyethylene bags (NUTRIGO, Sinaloa, Mexico) that were sealed to allow the slices to create the passive MAP. Permeability data of the film for $\mathrm{O}_{2}$ and $\mathrm{CO}_{2}$ were $0.07 \mathrm{~cm}^{3} / \mathrm{m}^{2} \cdot \mathrm{d} \cdot \mathrm{Pa}$ and $0.41 \mathrm{~cm}^{3} / \mathrm{m}^{2} \cdot \mathrm{d} \cdot \mathrm{Pa}$ at $25{ }^{\circ} \mathrm{C}$, respectively; while for water vapor transmission was $1.5 \times 10^{-4} \mathrm{~g} / \mathrm{m}^{2} \cdot \mathrm{d} \cdot \mathrm{Pa}$. The second group of slices was put into open containers (AIR). All groups were stored at $5{ }^{\circ} \mathrm{C}$ for 15 days.

\subsection{Gas measurements}

Gas composition $\left(\mathrm{O}_{2}\right.$ and $\left.\mathrm{CO}_{2}\right)$ within MAP was monitored every 5 days using a gas analyzer model GCS-150 (Gas Control Systems, Sparta, Michigan, USA). For analysis, gas was drawn from the headspace of each package through a septum using a syringe needle connected to the instrument.

\subsection{Visual quality index}

The quality of the slices was visually evaluated every 5 days based on the percentage of spoiled area on fruit surfaces according to Mercado-Silva et al. (1998) with some modifications, using a hedonic scale, where: $1=\operatorname{very}$ bad $(>50 \%$ spoiled area); $2=$ bad (20-50\% spoiled area); $3=$ moderate (marketing limit: $5-20 \%$ spoiled area); $4=$ good $(<5 \%$ spoiled area $) ; 5=$ excellent (without any damage). This evaluation was replicated six times.

\subsection{Browning index}

The browning of the fruit was assessed taking into account the extent of the total brown area of each slice as described by Mercado-Silva et al. (1998) with some modifications. The following 5 point scale was used: $0=$ none (without dark area); $1=$ light ( $<5 \%$ of dark area); $2=$ moderate (marketing limit: $5-20 \%$ of dark area); 3 = severe (consumption limit: $20-50 \%$ of dark area); $4=$ very severe $(>50 \%$ of dark area). Determinations were performed six times.

\subsection{Ascorbic acid content}

It was determined according to Ayón-Reyna et al. (2015). A portion of $30 \mathrm{~g}$ of frozen fruit was homogenized with $100 \mathrm{~mL}$ of degassed and cold deionized water using a commercial blender (Osterizer, Jarden, Rye, New York, USA) and filtered through organza cloth. A second filtration was done using $0.45 \mu \mathrm{m}$ disposable filters (Pall, Port Washington, New York, USA) followed by Sep-Pak C18 cartridges (Waters, Milford, Massachusetts, USA). A 1-mL aliquot was analyzed using a 1100 HPLC system (Agilent, Waldbronn, Germany) equipped with a Sphereclone ODS2 column $(250 \mathrm{~mm} \times 4.6 \mathrm{~mm} \times 5 \mu \mathrm{m}$, Phenomenex, Torrance, California, USA) operated at $16^{\circ} \mathrm{C}$. The mobile phase used was monobasic potassium phosphate $(25 \mathrm{mM})$ and the flow rate was $0.7 \mathrm{~mL} / \mathrm{min}$. The absorbance was determined at $254 \mathrm{~nm}$ during $15 \mathrm{~min}$ with an injection of $10 \mu \mathrm{L}$. Ascorbic acid content was calculated using a curve obtained with a commercial standard of ascorbic acid $(0.165-3.3 \mu \mathrm{L} / \mathrm{L})$ (Sigma-Aldrich, St. Louis, Missouri, USA) and expressed as grams per kilogram of fresh mass (FM). Nine repetitions were made for each treatment.

\subsection{Total phenolics content}

Phenolic compounds were determined according to Kähkönen et al. (1999) with some modifications. A 2.5 g sample was homogenized with $12.5 \mathrm{~mL}$ of $100 \%$ methanol and $0.5 \%$ sodium bisulfite using an Ultra-Turrax (IKA T18 basic Ultra-Turrax, IKA Werke, Staufen im Breisgau, Germany). The homogenate was centrifuged at $3200 \times g$ for $10 \mathrm{~min}$ at $4^{\circ} \mathrm{C}$. The supernatant was filtered in Whatman No. 1 paper (Whatman International, Maidstone, England) and the volume adjusted to $25 \mathrm{~mL}$ with $80 \%$ methanol. A $100 \mu \mathrm{L}$ aliquot of diluted extract was combined with $4 \mathrm{~mL}$ deionized water and $200 \mu \mathrm{L}$ of $1 \mathrm{M}$ Folin-Ciocalteu reagent, stirred, and allowed to rest for $2 \mathrm{~h}$, and then the absorbance was measured at $740 \mathrm{~nm}$ using a spectrophotometer (SQ2800; UNICO, New Jersey, USA). Total phenolics content was obtained using a standard calibration curve of gallic acid $(0-500 \mu \mathrm{g} / \mathrm{mL})$. Nine measurements were performed for each treatment. The results were expressed as grams of GAE (Gallic Acid Equivalent) per kilogram of fresh mass.

\subsection{Determination of PPO activity}

PPO activity was determined according to López-López et al. (2013). Enzyme extracts were obtained homogenizing $10 \mathrm{~g}$ of pineapple slices with $20 \mathrm{~mL}$ of $0.05 \mathrm{M} \mathrm{K}_{2} \mathrm{HPO}_{4}$ buffer ( $\mathrm{pH} 7.0$ ) containing $4 \%$ polyvinylpolypyrrolidone (PVPP), allowed to stand for $2 \mathrm{~h}$ in the dark at $4^{\circ} \mathrm{C}$, and then centrifuged at $14000 \times g$ for $1 \mathrm{~min}$ $\left(4^{\circ} \mathrm{C}\right)$ (Eppendorf 5804-R, Eppendorf, Hamburg, Germany); the supernatant was dialyzed against two changes of the same buffer over a period of $24 \mathrm{~h}$ at $4{ }^{\circ} \mathrm{C}$. The reaction was started by adding $900 \mu \mathrm{L}$ of $\mathrm{K}_{2} \mathrm{HPO}_{4}$ buffer $(0.05 \mathrm{M}, \mathrm{pH} 7.0)$ plus $500 \mu \mathrm{L}$ of $0.2 \mathrm{M}$ catechol in sodium citrate buffer $(0.1 \mathrm{M}, \mathrm{pH} 4.0)$, and $100 \mu \mathrm{L}$ of enzymatic extract into a quartz cuvette. Changes in absorbance at $420 \mathrm{~nm}$ were recorded every $10 \mathrm{~s}$ up to $5 \mathrm{~min}$ using a spectrophotometer (UNICO SQ 2800). One unit of activity (UA) was defined as a change in absorbance of 0.001 units $/ \mathrm{min}$. Protein content was determined according to Bradford (1976) using bovine serum albumin as a calibration standard (0-200 
$\mu \mathrm{g} / \mathrm{mL}$ ) at $595 \mathrm{~nm}$. The results were expressed as units of activity per milligrams of protein and six measurements were performed for each treatment.

\subsection{Statistical analysis}

A completely randomized experimental design with 3 replicates was performed, where 3 bags or containers with 5 slices each constituted a replicate. Statistical analysis of data was performed through multiple analysis of variance using Statgraphics Plus 5.1 (Statpoint Technologies, Warrenton, Virginia, USA) and the means were compared using Fisher's least significant difference (LSD) test $(p<0.05)$.

\section{Results and discussion}

\subsection{Oxygen and carbon dioxide concentration}

The $\mathrm{O}_{2}$ concentration inside the MAP decreased during the first 5 days of storage in untreated and AA treated slices, reaching values of $8 \%$ and $12 \%$, respectively (Figure $1 \mathrm{~A}$ ). This decrease was more pronounced in pineapple slices without antioxidant, which can be attributed to an increased metabolic activity of the fruit. In the case of slices treated with NAC and IAA, the $\mathrm{O}_{2}$ concentration inside the bags remained constant during the storage, which may be due to a positive effect of the treatments to reduce the deterioration processes and senescence of the pineapple slices. From day 10 until the end of the storage, no significant differences $(p<0.05)$ were observed for $\mathrm{O}_{2}$ concentration in all treatments.

Figure $1 \mathrm{~B}$ shows that the $\mathrm{CO}_{2}$ concentration had a contrary behavior compared to $\mathrm{O}_{2}$ concentration. Untreated slices had the highest accumulation of $\mathrm{CO}_{2}$ during the first 5 days followed by

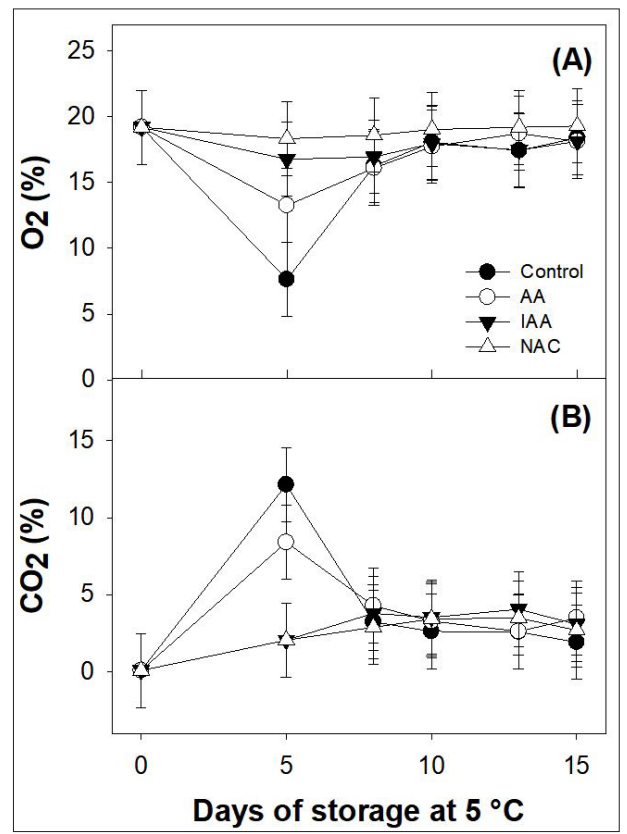

Figure 1. Changes in $\mathrm{O}_{2}(\mathrm{~A})$ and $\mathrm{CO}_{2}$ (B) concentrations inside passive MAP during storage at $5{ }^{\circ} \mathrm{C}$ of fresh-cut pineapple treated with antioxidants. Each point represents the mean of six determinations. Vertical bars indicate LSD $(p<0.05)$.
AA treated slices, which decreased by the tenth day and remained constant until the end of the storage. However, in NAC and IAA treatments, $\mathrm{CO}_{2}$ concentration remained constant during the storage period. This low production of $\mathrm{CO}_{2}$ in slices treated with NAC may be due to the fact that NAC has in its structure a thiol group $(-\mathrm{SH})$ that is covalently attached to acetic acid through a thioester bond, which may prevent the binding of CoA and acetic acid to form acetyl CoA that is oxidized in the Krebs cycle to produce $\mathrm{CO}_{2}$ (Lehninger, 2003). From day 10, all treatments obtained $\mathrm{CO}_{2}$ concentration values between 2-3\%, remaining without significant changes $(p<0.05)$ until day 15 .

Although $\mathrm{CO}_{2}$ concentrations above $2 \%$ can affect the ripening processes in tropical fruits, this may not be the case for fresh-cut products because their tolerance to low levels of

$\mathrm{O}_{2}$ and/or high $\mathrm{CO}_{2}$ is higher than that of whole fruits (Yahia, 1998). These results agree with those reported by Perkins-Veazie \& Collins (2004), and Benedetti et al. (2008), who found that $\mathrm{CO}_{2}$ increased while $\mathrm{O}_{2}$ decreased in fresh-cut watermelon and cantaloupe stored in MAP conditions, respectively.

\subsection{Visual quality index}

The quality index of pineapple slices stored in AIR conditions decreased as the storage time advanced, showing a rapid decrease during the first 5 days and a steady decline throughout the storage (Figure 2A). This rapid loss was due to the dehydrated appearance of the tissue surface by the loss of humidity, which causes the consumer rejection. A similar behavior was observed by Gil et al. (2006) who reported that during the first 6 days of storage the slices suffered an evident loss of commercial quality. After 5 days of storage, control slices were below the limit of marketability (3.0) while all antioxidant treated slices showed values near the limit. Fruits from control treatment reached by the end of storage a quality index of 1 (very bad, in the scale), meanwhile AA, IAA and NAC treatments reached values of 2.1,3.0, and 2.6, respectively, which were situated between bad and moderate visual quality index. Respect to the marketing limit, IAA treated slices were at the limit while slices treated with the other agents were non marketable.

In general, slices stored in passive MAP maintained for a longer period their initial quality (Figure $2 \mathrm{~B}$ ), with exception of the control slices that lost quickly their quality. Control slices obtained the lowest values (1.2) at day 10 of storage while AA, IAA and NAC maintained its initial quality. Visual quality index decreased for all treated slices at day 15, although IAA and NAC showed the highest values and they were still above the marketability limit.

At the end of the storage in AIR and passive MAP, it was found that control fruit had a bad appearance and the lowest quality index, whereas IAA and NAC slices showed the best quality. Gil et al. (2006) determined that the market limit of pineapple slices was on day 9 when they were stored in air at $5{ }^{\circ} \mathrm{C}$; however, when they were in an atmosphere with $2 \% \mathrm{O}_{2}$ and $10 \% \mathrm{CO}_{2}$, the marketing limit could reach up to 12 days. In the present study, the use of antioxidants reduced the spoiling of fresh-cut pineapple stored at $5^{\circ} \mathrm{C}$, keeping the fruit commercial quality for 10 days; but this effect was better when the slices were stored in passive MAP conditions. 


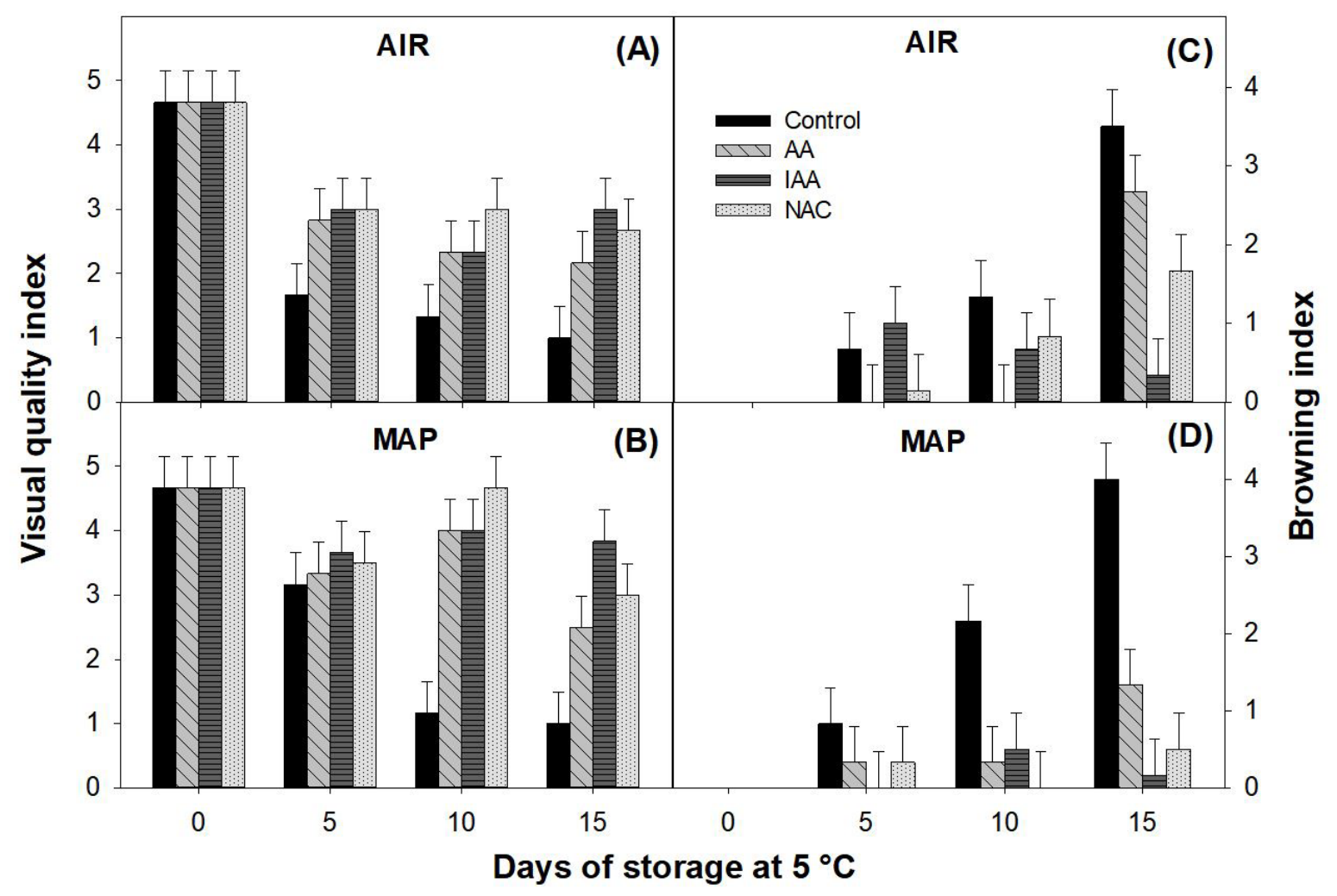

Figure 2. Changes in visual quality $(A, B)$ and browning indexes $(C, D)$ of fresh-cut pineapple treated with antioxidants and stored at $5{ }^{\circ} \mathrm{C}$ under AIR or passive MAP conditions. Values are means of six determinations. Vertical bars represent LSD $(p<0.05)$.

\subsection{Browning index}

An increase in the browning index during the storage in AIR conditions was observed for all pineapple slices (Figure 2C). At day 5, the slices treated with the antioxidant agents kept their characteristic coloration, with exception of the slices treated with IAA, which presented a light browning similar to that showed by the control slices. After 10 days of storage, control slices showed the highest browning index (1.3) followed by NAC and IAA treated slices that presented values between 0.6 and 0.8 . There was a considerable increase in browning index of control and AA slices at the end of storage, showing values of approximately $50 \%$ of dark area, which were above or near the limit of consumption. Pineapple slices treated with IAA showed the lowest browning index (0.3) qualified as light and still well below the marketing limit, while the slices treated with NAC showed values (about 1.6) qualified as moderate and closer to the marketing limit (2).

Slices packed in passive MAP (Figure 2D) showed lower values of browning index compared with AIR packed slices. Control slices observed a continuous increase in browning reaching the marketing limit at day 10 to end the storage with values of about 4.0, which were considered with a very severe darkening area. All the rest of slices were qualified below the limit of marketability during the whole storage period. The slices treated with IAA and NAC did not show any significant differences $(p<0.05)$ during the storage; they showed the lowest browning index (light, less than $5 \%$ of dark area). Pace et al. (2014) reported lower browning in fresh-cut lettuce when it was dipped in a solution containing cysteine. Also, Remorini et al. (2015) reported that ascorbic acid reduced the browning index of fresh-cut apples, which could be due to the interaction of AA with polyphenol oxidase and/or the regeneration of phenolics.

\subsection{Ascorbic acid content}

The ascorbic acid content of pineapple stored in AIR conditions showed a clear tendency to decrease (Figure 3A) being less pronounced in the control slices, which showed values from $0.16 \mathrm{~g} / \mathrm{kg}$ of fresh mass at the beginning to $0.057 \mathrm{~g} / \mathrm{kg}$ of fresh mass at the end. The greatest loss of ascorbic acid was observed in pineapple slices treated with IAA, followed by those treated with AA and NAC. It can be seen that initially the content of ascorbic acid was higher in the slices treated with AA and IAA due to the exogenous application of these compounds; this favored the initial accumulation of ascorbic acid in the pineapple tissue which despite of its decrease, it reached levels similar to those of the other treatments at day 15 . This reduction is possibly due to the fact that the ascorbic acid was converted into dehydroascorbic acid through a reversible reaction because fruits were exposed to air, and possibly later was converted into 2-3-dicetogulonic acid. A similar behavior was found by González-Aguilar et al. (2005) who observed an initial increment in the content of ascorbic acid in fresh-cut pineapple treated with AA, which decreased as the time progressed. Moreover, Cefola et al. (2014) showed that the accumulation of AA in tissues during storage of fresh-cut nectarines due to exogenous application caused 


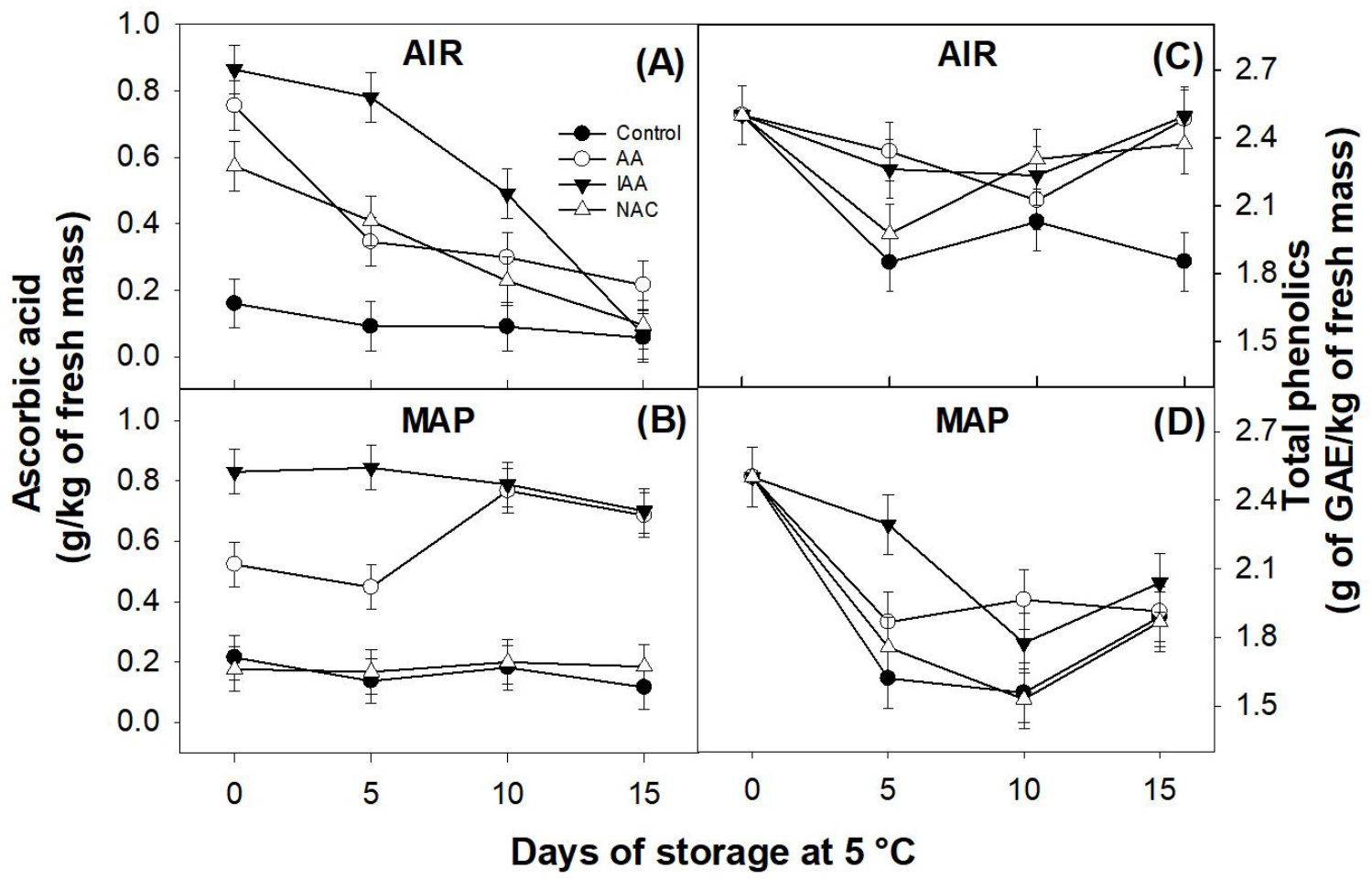

Figure 3. Ascorbic acid (A, B) and total phenolics (C, D) contents of fresh-cut pineapple treated with antioxidant agents and stored at $5{ }^{\circ} \mathrm{C}$ under AIR or passive MAP conditions. Values are means of nine determinations. Vertical bars represent LSD $(p<0.05)$.

an initial increase in total antioxidant activity followed by a progressive decrease within 5-6-days in storage. Despite of the fact that the slices treated with NAC had high initial values, their content reached lower levels similar to those observed for the control in the day 15. These results agree with Mohamed et al. (1993) who observed a higher retention of ascorbic acid and a reduction in the change of color during the storage of dehydrated pickled pineapple and guava previously treated with cysteine. González-Aguilar et al. (2008) found out that the application of citric acid and AA prevented the degradation of the vitamin C, suggesting that the oxidative reactions were the main cause of deterioration, and that the use of antioxidants could prevent such losses, which could favor to obtain fresh-cut products with a final content of ascorbic acid similar to that of fresh fruits.

At the beginning of evaluations in passive MAP, all slices showed different values of ascorbic acid and highest value corresponded to IAA treated fruit with $0.83 \mathrm{~g} / \mathrm{kg}$ of fresh mass, followed by AA slices with $0.52 \mathrm{~g} / \mathrm{kg}$ of fresh mass while control and NAC obtained the lowest contents (about $0.2 \mathrm{~g} / \mathrm{kg}$ of fresh mass) (Figure 3B). These high values were attributed to the exogenous application of the antioxidant solutions. Remarkably, control, IAA, and NAC treated slices maintained the ascorbic acid contents for the entire storage period in passive MAP, which can be considered a beneficial effect due to the retention of the nutritional quality; especially those that were enriched with the antioxidants. In the case of the slices treated with $\mathrm{AA}$, an increase in ascorbic acid content was observed at day 10 reaching values of $0.77 \mathrm{~g} / \mathrm{kg}$ of fresh mass, perhaps as a result of biosynthetic and degradative reactions; however, this treatment also maintained the content until the end of storage.
Similar results were observed by Tudela et al. (2002) in fresh-cut potatoes and by González-Aguilar et al. (2005) in fresh-cut pineapple, who noticed that the initial content of ascorbic acid was maintained constant during the storage.

\subsection{Total phenolics content}

The initial phenolics content in the pineapple slices stored under AIR conditions was approximately $2.5 \mathrm{~g}$ of GAE $/ \mathrm{kg}$ of fresh mass (Figure 3C). This value decreased significantly for control slices and for those treated with NAC during the first 5 days of storage, reaching the lowest values (about $2 \mathrm{~g}$ of GAE $/ \mathrm{kg}$ of fresh mass), which remained constant in control slices but in NAC they tended to increase during the rest of storage period. At the end, the pineapple slices treated with antioxidant agents reached similar levels of phenolics which were significantly higher than control. These results agree with previous reports about pineapple, where AA and IAA treatments reduced the loss of phenolics (González-Aguilar et al., 2005), because AA and IAA reduce the quinones, product of the $\mathrm{PPO}$ reaction with the phenolic compounds, preventing the browning of fresh-cut fruits and vegetables. The reduction in phenolics content observed for control fruit in the present study may be due to the fact that they were used as substrates by the PPO, producing compounds that provoke the browning in the pineapple surface (Kumar et al., 2013).

Respect to the initial values, total phenolics content decreased in all pineapple slices stored in passive MAP (Figure 3D). The slices treated with IAA showed the highest phenolics content at day 5 , but at the end of the storage there were no significant differences 
in phenolics between the treatments. The decrease in phenolics observed for slices under passive MAP does not correspond with the results obtained by Heredia \& Cisneros-Zevallos (2009) in carrot, who found that the phenolics synthesis was higher in the first 6 days of storage, which was attributed to the stress caused by the process of cutting; however, in our case we attribute the decrease in phenolics to their oxidation by PPO.

Taking into account the behavior of both storage conditions, the slices that had the lowest browning index also showed the lowest loss of phenolics content in both, AIR and passive MAP. Similar results were found in jicama cylinders and loquat fruit, where the phenolics content was highly correlated with the browning index (Aquino-Bolaños \& Mercado-Silva, 2004; Abbasi et al., 2013).

\subsection{PPO activity}

The evolution of this enzyme showed a rapid decrease in the first 5 days of storage under AIR conditions without significant differences among treatments (Figure $4 \mathrm{~A}$ ), this decrease was probably due to the reduction in the water activity caused by the dehydration of the tissue, since part of the free water was lost during the storage, which way have reduced the relative speed of the PPO enzyme reaction (Badui-Dergal, 2012).

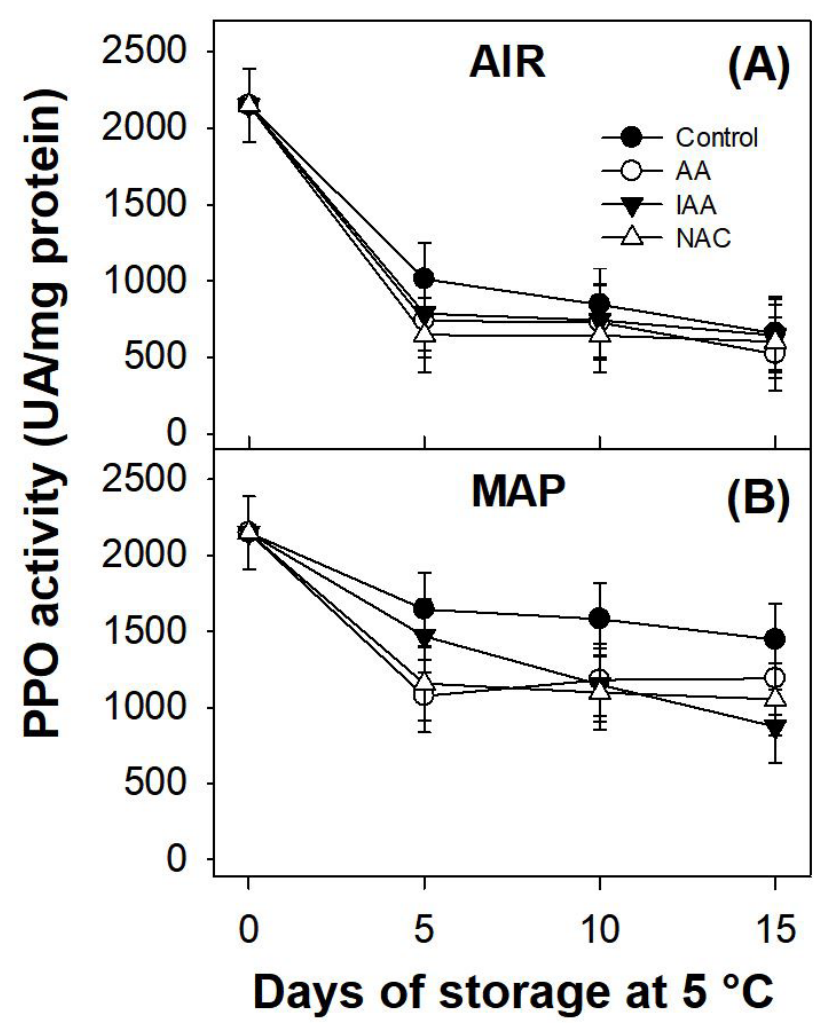

Figure 4. Evolution of polyphenol oxidase activity in fresh-cut pineapple treated with antioxidant agents and stored at $5{ }^{\circ} \mathrm{C}$ under AIR (A) or passive MAP (B) conditions. Values are means of six determinations. Vertical bars represent LSD $(p<0.05)$.
A similar tendency was observed for the pineapple slices stored in passive MAP (Figure 4B), but with higher remaining activity. This tendency was previously reported by Lamikanra \& Watson (2001) in apple and by Oms-Oliu et al. (2006) in pear. The PPO activity decreased in control slices from $2150 \mathrm{UA} / \mathrm{mg}$ to $1650 \mathrm{UA} / \mathrm{mg}$ protein at day 5 , remaining constant during the rest of the storage and being higher compared with the activity observed in the slices treated with antioxidants. The low activity of the antioxidant treated slices may be due to the fact that AA and cysteine are good reducing agents that prevent the browning associated with PPO activity (Gorny et al., 2002). A relation was observed between the enzyme activity, the presence of browning and total phenolics content, being the control slices those that showed the highest PPO activity and browning index and the lowest phenolics content; while the IAA treated slices showed the lowest values in enzyme activity and browning and the highest phenolics content. Similar results were reported by González-Aguilar et al. (2005) in fresh-cut pineapple treated with antioxidants. Also, Kumar et al. (2013) observed that the browning was positively correlated with the PPO activity.

\section{Conclusions}

The application of antioxidants and MAP favored the shelf life of the fresh-cut pineapple for 10 days compared with the untreated fruit. The exogenous application of AA and IAA increased the content of ascorbic acid 4.7 and 5.4 times, respectively. In addition, the applied antioxidants favored the inhibition of PPO activity from the fifth day. The application of IAA in fresh-cut pineapple followed by storage under passive MAP conditions increased the ascorbic acid content about 4 times and maintained it throughout the storage; also, this treatment favored a higher retention of total phenolics content ( $2 \mathrm{~g}$ of GAE/ $\mathrm{kg}$ of fresh mass), as well as lower browning index (0.17) and enzymatic activity ( $873 \mathrm{UA} / \mathrm{mg}$ protein) at the end of the storage. These results suggest that the combination of IAA and MAP is the best alternative to offer products that contribute to the health benefits associated to dietary consumption of fruits. This combination may be considerate a good way of conservation of fresh-cut products because it maintains quality of pineapple attending the consumer desire of convenience and fresh-like appearance.

\section{Acknowledgements}

To Universidad Autonoma de Sinaloa (PROFAPI 2008/180) for financial support.

\section{References}

Abbasi, N. A., Akhtar, A., Hussain, A., \& Ali, I. (2013). Effect of antibrowning agents on quality changes of loquat [Eriobotrya japonica (Thunb.) Lindley] fruit after harvest. Pakistan Journal of Botany, 45, 1391-1396.

Aquino-Bolaños, E. N., \& Mercado-Silva, E. (2004). Effects of polyphenol oxidase and peroxidase activity, pbhenolics and lignin content on the browning of cut jicama. Postharvest Biology and Technology, 33(3), 275-283. http://dx.doi.org/10.1016/j.postharvbio.2004.03.009.

Ayón-Reyna, L. E., Tamayo-Limón, R., Cárdenas-Torres, F., LópezLópez, M. E., López-Angulo, G., López-Moreno, H. S., López- 
Cervántes, J., López-Valenzuela, J. A., \& Vega-García, M. O. (2015). Effectiveness of hydrothermal-calcium chloride treatment and chitosan on quality retention and microbial growth during storage of fresh-cut papaya. Journal of Food Science, 80(3), 594-601. http:// dx.doi.org/10.1111/1750-3841.12783. PMid:25627320.

Badui-Dergal, S. (2012). Química de los alimentos (5th ed.). Naucalpan de Juarez: Pearson Educación.

Benedetti, B. C., Gómez, P., Martins, M., Conesa, A., \& Artés, F. (2008). Effect of pre-processing controlled atmosphere storage on the quality of fresh-cut Galia melons. International Journal of Food Science \& Technology, 14(5 Suppl.), 13-19. http://dx.doi. org/10.1177/1082013208095687.

Bradford, M. M. (1976). A rapid and sensitive method for the quantitation of microgram quantities of protein utilizing the principle of proteindye binding. Analytical Biochemistry, 72(1-2), 248-254. http://dx.doi. org/10.1016/0003-2697(76)90527-3. PMid:942051.

Cefola, M., Pace, B., Sergio, L., Baruzzi, F., Gatto, M. A., Carito, A., Linsalata, V., Cascarano, N. A., \& Di Venere, D. (2014). Postharvest performance of fresh-cut 'Big Top' nectarine as affected by dipping in chemical preservatives and packaging in modified atmosphere. International Journal of Food Science \& Technology, 49(4), 1184-1195. http://dx.doi.org/10.1111/ijfs.12415.

Chiabrando, V., \& Giacalone, G. (2012). Effect of antibrowning agents on color and related enzymes in fresh-cut apples during cold storage. Journal of Food Processing and Preservation, 36(2), 133-140. http:// dx.doi.org/10.1111/j.1745-4549.2011.00561.x.

Gil, M. I., Aguayo, E., \& Kader, A. A. (2006). Quality changes and nutrient retention in fresh-cut versus whole fruits during storage. Journal of Agricultural and Food Chemistry, 54(12), 4284-4296. http://dx.doi.org/10.1021/jf060303y. PMid:16756358.

González-Aguilar, G. A., Celis, J., Sotelo-Mundo, R., De la Rosa, L., Rodrigo-García, J., \& Álvarez-Parrilla, E. (2008). Physiological and biochemical changes of different fresh-cut mango cultivars stored at $5{ }^{\circ} \mathrm{C}$. International Journal of Food Science \& Technology, 43(1), 91-101. http://dx.doi.org/10.1111/j.1365-2621.2006.01394.x.

González-Aguilar, G. A., Ruiz-Cruz, S., Soto-Valdez, H., Vázquez-Ortiz, F., Pacheco-Aguilar, R., \& Wang, C. Y. (2005). Biochemical changes of fresh-cut pineapple slices treated with antibrowning agents. International Journal of Food Science \& Technology, 40(4), 377-383. http://dx.doi.org/10.1111/j.1365-2621.2004.00940.x.

Gorny, J. R., Hess-Pierce, B., Cifuentes, R. A., \& Kader, A. A. (2002). Quality changes in fresh-cut pear slices as affected by controlled atmospheres and chemical preservatives. Postharvest Biology and Technology, 24(3), 271-278. http://dx.doi.org/10.1016/S09255214(01)00139-9.

Heredia, J. B., \& Cisneros-Zevallos, L. (2009). The effect of exogenous ethylene and methyl jasmonate on PAL activity, phenolic profiles and antioxidant capacity of carrots (Daucus carota) under different wounding intensities. Postharvest Biology and Technology, 51(2), 242-249. http://dx.doi.org/10.1016/j.postharvbio.2008.07.001.

Kähkönen, M. P., Hopia, A. I., Vuorela, H. J., Rauha, J., Pihlaja, K., Kujala, S. T., \& Heinonen, M. (1999). Antioxidant activity of plant extracts containing phenolic compounds. Journal of Agricultural and Food Chemistry, 47(10), 3954-3962. http://dx.doi.org/10.1021/ jf990146l. PMid:10552749.
Kumar, D., Mishra, D. S., Chakraborty, B., \& Kumar, P. (2013). Pericarp browning and quality management of litchi fruit by antioxidants and salicylic acid during ambient storage. Journal of Food Science and Technology, 50(4), 797-802. http://dx.doi.org/10.1007/s13197011-0384-2. PMid:24425984.

Lamikanra, O., \& Watson, M. A. (2001). Effects of ascorbic acid on peroxidase and polyphenoloxidase activities in fresh-cut cantaloupe melon. Journal of Food Science, 66(9), 1283-1286. http://dx.doi. org/10.1111/j.1365-2621.2001.tb15202.x.

Lehninger, A. L. (2003). Bioquímica (2nd ed.). Barcelona: Ediciones Omega.

López-López, M., Vega-Espinoza, A., Ayón-Reyna, L., López-Valenzuela, J., \& Vega-García, M. (2013). Combined effect of hot water dipping treatment, $\mathrm{N}$-acetylcysteine and calcium on quality retention and enzymatic activity of fresh-cut apple. Journal of Food Agriculture and Environment, 11, 243-248.

Luo, Z., Li, D., Xie, J., Feng, S., \& Wang, Y. (2014). Effects of heat treatment on quality and browning of fresh-cut sugarcane. Journal of Food Processing and Preservation, 39(6), 688-696. http://dx.doi. org/10.1111/jfpp.12278.

Mercado-Silva, E., Rubatzky, V., \& Cantwell, M. I. (1998). Variation in chilling susceptibility of jicama roots. Acta Horticulturae, (467), 357-362. http://dx.doi.org/10.17660/ActaHortic.1998.467.40.

Mohamed, S., Kyi, K. M. M., \& Sharif, Z. M. (1993). Protective effects cysteine-HCl on vitamin $\mathrm{C}$ in dehydrated pickled candied pineapple and guava. Journal of the Science of Food and Agriculture, 61(1), 133-136. http://dx.doi.org/10.1002/jsfa.2740610122.

Oliveira, M., Abadias, M., Usall, J., Torres, R., Teixidó, N., \& Viñas, I. (2015). Application of modified atmosphere packaging as a safety approach to fresh-cut fruits and vegetables: a review. Trends in Food Science \& Technology, 46(1), 13-26. http://dx.doi.org/10.1016/j. tifs.2015.07.017.

Oms-Oliu, G., Aguiló-Aguayo, I., \& Martín-Belloso, O. (2006). Inhibition of browning on fresh-cut pear wedges by natural compounds. Journal of Food Science, 71(3), 216-224. http://dx.doi. org/10.1111/j.1365-2621.2006.tb15644.x.

Pace, B., Capotorto, I., Ventura, M., \& Cefola, M. (2014). Evaluation of $\mathrm{L}$-cysteine as anti-browning agent in fresh-cut lettuce processing. Journal of Food Processing and Preservation, 39(6), 985-993. http:// dx.doi.org/10.1111/jfpp.12312.

Perkins-Veazie, P., \& Collins, J. K. (2004). Flesh quality and lycopene stability of fresh-cut watermelon. Postharvest Biology and Technology, 31(2), 159-166. http://dx.doi.org/10.1016/j.postharvbio.2003.08.005.

Remorini, D., Landi, M., Tardelli, F., Lugani, A., Massai, L., Graziani, G., Fogliano, V., \& Guidi, L. (2015). Effect of chlorine dioxide and ascorbic acid on enzymatic browning and shelf life of fresh-cut Red Delicious and Granny Smith apples. Journal of Food Processing and Preservation, 39(6), 2925-2934. http://dx.doi.org/10.1111/jfpp.12544.

Tudela, J. A., Espín, J. C., \& Gil, M. I. (2002). Vitamin C retention in fresh-cut potatoes. Postharvest Biology and Technology, 26(1), 75-84. http://dx.doi.org/10.1016/S0925-5214(02)00002-9.

Yahia, E. (1998). Modified and controlled atmospheres for tropical fruits. Horticultural Reviews, 22, 123-183. 